\title{
Bactericidal Permeability-Increasing Protein
}

National Cancer Institute

\section{Source}

National Cancer Institute. Bactericidal Permeability-Increasing Protein. NCI Thesaurus.

Code C106602.

Bactericidal permeability-increasing protein (487 aa, $~ 54 \mathrm{kDa}$ ) is encoded by the human BPI gene. This protein is involved in both defense against gram-negative bacterial infections and lipopolysaccharide binding. 